\title{
Locally-developed External Fixators as Definitive Treatment of Open Tibia Diaphyseal Fractures: A Clinical Prospective Study Conducted in Ivory Coast
}

Kouamé Jean-Eric Kouassi ( $\square$ medericko@yahoo.fr)

Catholic University of Louvain: Universite Catholique de Louvain https://orcid.org/0000-0003-4757$547 X$

\section{Jean Régis Akobé}

Universite Alassane Ouattara UFR Sciences Medicales: Universite Alassane Ouattara Unite de Formation et de Recherche Sciences Medicales

Aya Adélaïde Natacha Kouassi

Université Alassane Ouattara UFR Sciences Médicales: Universite Alassane Ouattara Unite de Formation et de Recherche Sciences Medicales

\section{Loïc Founkoué}

UCL: Universite Catholique de Louvain

Christine Detrembleur

UCL: Universite Catholique de Louvain

\section{Michel Kodo}

Université Alassane Ouattara UFR Sciences Médicales: Universite Alassane Ouattara Unite de Formation et de Recherche Sciences Medicales

Olivier Cornu

UCL: Universite Catholique de Louvain

\section{Research article}

Keywords: definitive treatment, external fixator, development, emerging country, open diaphyseal tibia fracture

Posted Date: December 1st, 2020

DOI: https://doi.org/10.21203/rs.3.rs-116154/v1

License: (c) (i) This work is licensed under a Creative Commons Attribution 4.0 International License.

Read Full License 
Version of Record: A version of this preprint was published at International Orthopaedics on July 31st, 2021. See the published version at https://doi.org/10.1007/s00264-021-05073-7. 


\section{Abstract}

Background: This study sought to evaluate the effectiveness of locally-developed external fixators (LDEF) as definitive treatment for open tibia diaphyseal fractures (OTDF) in Ivory Coast.

Methods: Gustilo I, II and IIIA OTDFs of patients admitted within 24 hours of injury were prospectively included and treated with a locally-developed external fixator. The rates of union, mal-union, septic complications, as well as the functional results were assessed, in addition to the LDEF construct's integrity. Predictive factors of failure or poor results were assessed.

Results: Overall, 40 OTDF patients were admitted within 24 hours of injury. Gustilo I, II and IIIA fractures were observed in three, 13, and 24 patients, respectively. Uneventful fracture healing was obtained in 29 cases, with an average union time of 8.47 months. Mal-union and non-union were registered in three and four cases, respectively. Pin-track infection (PTI) was observed in 13 cases, and deep infection in seven. Infection resolved in all patients except four, who developed chronic osteomyelitis. None of the nonunions were associated with an infection. The overall functional result was satisfactory in 32 patients. PTI was the only predictive factor for chronic infection. Biplanar frames, when compared to monoplanar constructs, were associated with a significantly improved functional outcome.

Conclusion: In comparison with the results obtained in the same environment without a locally-developed external fixator, the provision of such a device improved significantly the OTDF management, as it provided better stability and superior fracture healing rates. PTI remains an essential problem but with, hopefully, limited negative consequences.

Trial registration: This study protocol was registered in Pan African Clinical Trial Registry under NPACTR202009854874448. Date of registration 28 September 2020 'retrospectively registered'. www.pactr.org.

\section{Introduction}

Among open long bone fractures, open tibia fractures are the most common [1]. They are a frequent cause of hospital admissions following road traffic injuries, and they are associated with increased mortality and morbidity [2]. This setting is all the more alarming in developing countries, such as Ivory coast, where the traffic safety norms are often ignored, along with poor traffic management [3]. Despite advances made in fracture treatment, including routine prophylactic antibiotics, prompt debridement, and early softtissue coverage, these injuries result in high rates of infection and non-union [4]. While appropriate open tibial fracture treatment appears crucial, the optimum method of definitive skeletal stabilization is still unclear [5]. In developed countries, primary debridement and intramedullary nailing are progressively becoming the preferred treatment of these fractures [6]. However, the situation differs in developing countries like Ivory Coast, where patients present late at hospitals and because adequate facilities in terms of manpower and theatres are not always available [7]. In our hospital, as in most centers in less developed regions, open tibial fractures have been traditionally managed by casting with Plaster of Paris 
(POP)[7]. The high failure rate that was associated with this management protocol made us look into a locally-developed external fixator as an alternative to the commercially available external fixators and POP. External fixation provides fracture stabilization with minimal soft-tissue disturbance [6]. In austere environments, however, a greater infection risk $[6,8]$ and concerns regarding sterility [9] have led numerous surgeons to minimally employ internal implants so as to limit wound infection risk. Moreover, the implants for external fixation can be reused readily, thus rendering them more available and affordable in low- and middle-income countries [10]. Although numerous sophisticated models are available on the market, they prove to be ather expensive [11]. The development of a locally-developed external fixator (LDEF) sought to build an inexpensive external fixator, whose biomechanical properties are comparable to those of a validated reference fixator [12]. The final objective was that patients who could not afford conventional expensive fixators would nevertheless be treated appropriately. This study describes the outcomes of a group of patients with open tibia diaphyseal fractures treated using this LDEF. This study sought to evaluate the LDEF effectiveness as definitive treatment for open tibia fractures, with the underlying hypothesis that the fracture healing rate and functional outcome would be improved with LDEF, as well.

\section{Methods}

\section{Study design}

This prospective study was carried out at University Teaching Hospital Bouake, Ivory Coast. The study was conducted from June 2019 to October 2020. The local ethics committee approved the study protocol, and written consent was obtained from all patients before participation in the study.

\section{Patients}

Consecutive patients presenting with open tibia diaphyseal fracture at consultation were eligible for the study. The inclusion criteria were patients older than 18 years with Gustilo-Anderson [13] Type I, II, IIIA open tibia diaphyseal fractures admitted to the hospital within 24 hours of injury. The exclusion criteria were open tibial fractures with intra-articular extension, Type IIIB fractures and Type IIIC according to Gustilo-Anderson, those who underwent initial debridement before arrival in our hospital, and those with neglected open tibial fractures. All the patients excluded from participation were treated appropriately. A total of 40 consecutive patients fulfilled the inclusion criteria and were entered into the study.

\section{Management}

An intravenous antibiotic therapy was established upon patient admission, combining ceftriaxone $2 \mathrm{~g}$ per day, metronidazole $1.5 \mathrm{~g}$ per day, and gentamicine $160 \mathrm{mg}$ per days for 5 days. This regime was followed by ciprofloxacin $750 \mathrm{mg}$ twice per day for 2 weeks. Tetanus prophylaxis was systematically administered to all patients.

Under spinal anesthesia, patients were operated on in the supine position. Thorough irrigation and debridement were performed in order to eliminate all contaminants, as well as highly contaminated or 
necrotic soft tissue.

Fractures were stabilized using a locally-developed external fixator (LDEF) (Fig. 1). The fixator design consisted of a unilateral uniplanar external fixator or biplanar external fixator [12] (Fig. 2), with the frame made of a $304 \mathrm{~L}$ stainless steel cylindrical tube. The standard tube was provided with a $20 \mathrm{~mm}$ gauge, $3 \mathrm{~mm}$, and $300 \mathrm{~mm}$ length. The tube was drilled into a perpendicular plane, with holes passing $5.2 \mathrm{~mm}$ in diameter, spaced $20 \mathrm{~mm}$ apart. The holes accept all types of pins that have a diameter $\leq 5 \mathrm{~mm}$. Threaded holes are perpendicular to those of the pins, which also accept hexagonal and flat-bottom screws that secure the tube/pins. To constitute a biplanar model, two full bars, $6 \mathrm{~mm}$ in diameter, ensure the connection between both main cylindrical tubes through four hollow tubes, $13 \mathrm{~mm}$ in diameter and $40 \mathrm{~mm}$ in length, which are attached to the four extremities of the main tubes. Five-millimeter diameter thread screws (M5) secure the tube/tube and bar/tube fixations.

Early coverage of the fracture site was achieved by means of suturing for Gustilo Types I and II fractures and by means of flaps (fascio-cutaneous, muscular) for Gustilo Type IIIA.

\section{Postoperative management}

The patients were invited to perform early knee and ankle joint movements and muscular exercises, as well. Patient were instructed to clean the device regularly with water. One month following the initial operation, follow-up radiographs (X-rays) were obtained in order to evaluate the fracture union progress. The LDEF condition was additionally assessed. Subsequently, gradual weight-bearing was permitted. Patients then returned for both clinical and radiological assessments every 2 months until the fracture was united. During this period, full weight bearing was permitted if an adequate bridging callus was visible on radiographs. Union of the fracture was defined clinically when the patient was able of fully weight bearing without any pain at the fracture site; fracture union was defined radiographically when the callus bridged at least three cortexes [14]. Mal-union was defined as a valgus or varus, both with an angulation of more than 5 degrees, anterior or posterior angulation of more than 10 degrees, or malrotations of more than $1 \mathrm{~cm}$ shortening $[15,16]$. Non-union was defined as a lack of fracture callus progression on two consecutive radiographs taken at least 3 months apart starting at 6 months postoperative or as a fracture requiring a surgical revision [17].

Infection was subdivided into superficial or pin-track infection, deep tissue infection, and chronic osteomyelitis. A pin-track infection (PTI) was defined as inflammation around the pin-track. PTIs were treated by cleaning each pin-site with a sterile pad application soaked in Dakin cooper, along with new daily dressing. Oral antibiotics (amoxicillin-clavulanic acid $1 \mathrm{gr} \times 3$ per day) were prescribed for 5 to 10 days. If the infection persisted, a culture of the site was carried out, and the antibiotic was adapted according to antibiogram results. X-rays were performed to assess if pin loosening had occurred. Loose pins would immediately be removed and not be replaced. A deep infection was defined as an infection involving deeper tissues, such as muscular fascia and bone [16], which require surgical debridement and appropriate antibiotics. Osteomyelitis was defined as the occurrence of more than two of the following signs/symptoms (> $38{ }^{\circ} \mathrm{C}$ temperature, localized swelling, localized heat, localized tenderness, and 
drainage at site), in addition to positive bone cultures or X-ray evidence of infection or infection recurrence following a primary apparently healed infection episode [18].

The external fixation system was removed, as an outpatient procedure, when fracture union was complete. Upon clinical examination, knee and ankle range of movement were examined by an independent examiner using a goniometer, in comparison to the contralateral healthy side $[7,19]$. The functional outcome measures were assessed at the last visit, including pain, knee and ankle motion ranges, and ability to return to normal walking, according to the Kitoko et al criteria [20] (Table 1).

Table 1

Kitoko RA et al. criteria for functional assessment following treatment of open tibia fracture

\begin{tabular}{|lllll|}
\hline & Very Good & Good & Fair & Poor \\
\hline Criterion & $\begin{array}{l}\text { Normal } \\
\text { walking }\end{array}$ & $\begin{array}{l}\text { Normal } \\
\text { walking }\end{array}$ & Pain when walking & $\begin{array}{l}\text { Frequent pain and } \\
\text { reduced mobility }\end{array}$ \\
& $\begin{array}{l}\text { Knee flexion }> \\
120^{\circ}\end{array}$ & $\begin{array}{l}\text { Knee flexion } \geq \\
90^{\circ}\end{array}$ & Knee flexion $60^{\circ}-90^{\circ}$ & Knee flexion $<60^{\circ}$ \\
& $\begin{array}{l}\text { Full knee } \\
\text { extension }\end{array}$ & $\begin{array}{l}\text { Extension to } \\
10^{\circ}\end{array}$ & $\begin{array}{l}\text { Knee extension deficit } \\
\text { of more than } 10^{\circ}\end{array}$ & $\begin{array}{l}\text { Knee extension } \\
\text { deficit of over } 15^{\circ}\end{array}$ \\
& $\begin{array}{l}\text { Ankle } \\
\text { dorsiflexion at }\end{array}$ & $\begin{array}{l}\text { Ankle } \\
\text { dorsiflexion at } \\
20^{\circ}\end{array}$ & $\begin{array}{l}\text { Ankle dorsiflexion at } \\
15^{\circ}\end{array}$ & $\begin{array}{l}\text { Ankle dorsiflexion at } \\
5^{\circ}\end{array}$ \\
& $\begin{array}{l}\text { Ankle plantar } \\
\text { flexion at } 50^{\circ}\end{array}$ & $\begin{array}{l}\text { Ankle plantar } \\
\text { flexion at } 30^{\circ}\end{array}$ & $\begin{array}{l}\text { Ankle plantar flexion at } \\
20^{\circ}\end{array}$ & $\begin{array}{l}\text { Ankle plantar flexion } \\
\text { at 10 }\end{array}$ \\
\hline $\begin{array}{l}\text { Overall } \\
\text { functional } \\
\text { result }\end{array}$ & Satisfactory & & Unsatisfactory & \\
\hline
\end{tabular}

\section{Primary outcome}

The primary outcome was the union rate of open tibia fracture.

\section{Secondary outcomes}

Secondary outcomes included:

(1) infection type and rate, and late complication rates (non-union, mal-union, and osteomyelitis);

(2) functional outcomes as measured using the validated Lower Extremity Functional Scale (LEFS) [21, 22]. Total scores range from 0 to 80 , with function defined as follows: extreme difficulty or unable to perform activity (0-19 points), quite a bit of difficulty (20-39 points), moderate difficulty (40-59 points), a little bit of difficulty (60-79 points), and no difficulty (80 points)[23]; 
(3) the health status was measured using the 12-Item Short Form Survey (SF-12). [24]. The SF-12 is a reliable generic health status instrument that has been validated for use in trauma patients. This scoring system consists of a Physical Component Summary (PCS-12) score and Mental Component Summary (MCS-12) score. Scores $\geq 50$ represent no disability; 40-49 mild disability; 30-39 moderate disability; below 30 severe disability [25]. All questionnaires were completed by the patients during their visit.

\section{Assessment parameters}

We collected and assessed data on demographics, risk factors (smoking, alcohol); mechanism of injury, admission delay in hospital, pattern and location of fracture, Gustilo fracture classification after debridement, in addition to associated injury. The hospital stay duration was analyzed. The fracture healing, duration of external fixation, time to fusion, and complications (infection, PTI, mal-union, and non-union) as well as functional results were analyzed.

\section{Statistical analysis}

Under our conditions, the union rate was $35 \%$ with the standard of care, without LDEF [7]. This study aimed to reach a union rate of $70 \%$. Assuming a significance level of $5 \%$ and power of $80 \%$, a minimum of 37 patients would be needed. A total of 40 patients were enrolled in this study.

Statistical analyses were performed using Sigma plot 13.0 software. Descriptive statistics were performed for quantitative variables (mean, standard deviation, minimum, maximum) and qualitative variables (frequency). A multiple logistic regression model was employed to determine the risk factors of infection (infection state $=1$ ) and bone complications (bone complications state $=1$ ). Independent variables were age (years), gender, fracture line, location of fracture, Gustilo grading, treatment delay, external fixator type, and pin-track infections. A Fisher's exact test was performed to test the null hypothesis of no association between functional outcome and frame type (monoplanar versus biplanar). A p-value $<0.05$ was considered statistically significant.

\section{Results}

Overall, 40 patients were admitted with OTDF within 24 hours of injury. The mean age of the patients was $32.77 \pm 12.55$ years (range: $18-77$ ). Patients aged $\geq 30$ years were predominated $(n=22 ; 55 \%)$. The injury cause was a road traffic accident in $38(95 \%)$ cases. The fracture type according to Gustilo classification was Type IIIA in 24 (60\%). The mean treatment delay was $26.35 \pm 13.49$ hours (range: $10-72)$. The patient characteristics are showed in Table 2. 
Table 2

Characteristics of patients

\begin{tabular}{|ll|}
\hline Variable & $\mathrm{n}(\%)$ \\
\hline Age (years) & \\
\hline Mean \pm SD (range) & $32.77 \pm 12.55(18-77)$ \\
\hline Gender & \\
\hline Male & $29(72.5 \%)$ \\
\hline Female & $11(27.5 \%)$ \\
\hline Mechanism of injury & \\
\hline Road trafic accident & $38(95 \%)$ \\
\hline Other & $2(5 \%$ \\
\hline Fracture line & \\
\hline Comminution & $36(90 \%)$ \\
\hline Simple & $4(10 \%)$ \\
\hline Gustilo-Anderson grading & \\
\hline I & $3(7.5 \%)$ \\
\hline II & $13(32.5 \%)$ \\
\hline IIIA & $28(70 \%)$ \\
\hline Location in the diaphysis & $26(72.5 \%)$ \\
\hline Proximal-third & $26(65 \%)$ \\
\hline Middle-third & \\
\hline Distal-third & \\
\hline Treatment delay & \\
\hline$\leq 24$ hours & \\
\hline$>24$ hours & \\
\hline Type external fixator & \\
\hline Monoplanar & \\
\hline Biplanar & \\
\hline Average hospital stay duration (days) & $8.98 \%)$ \\
\hline
\end{tabular}


The union rate was 29 (72.5\%) with an average union time of $8.47 \pm 1.66$ (range: $5-11$ ) months (Fig. 3). Deep infection and pin-track infections rates were 17.5\% (seven cases) and 32.5\% (13 cases), respectively. Pin-track infections were successfully treated with oral antibiotics and pin-site care without any pin-loosening registered. Complications were observed in 11 cases $(27.5 \%)$, including aseptic nonunion in four $(10 \%)$, mal-union in three $(7.5 \%)$, and osteomyelitis in the remaining four $(10 \%$, two considered PTI-related).

Throughout the treatment period, no implant failure, pin-breakage, pin-loosening were observed.

Extraction was performed locally without anesthesia. No refracture was observed during the follow- up period.

The functional outcomes were very good in 17 patients, good in 15, fair in six, and poor in the remaining two. The overall result was satisfactory in 32 cases and unsatisfactory in eight (Fig. 4). The mean SF-12 physical and mental scores were 42.54 and 46.45 , respectively, meaning mild disability. The mean ELFS scale was $61.53 \pm 10.50$, meaning a little bit of difficulty (Table 3 ).

Table 3

Functional outcomes

\begin{tabular}{|ll|}
\hline Variable & $\mathbf{n}(\%)$ \\
\hline Very good & $17(42.5 \%)$ \\
\hline Good & $15(37.5 \%)$ \\
\hline Fair & $6(15 \%)$ \\
\hline Poor & $2(5 \%)$ \\
\hline SF-12 score & \\
\hline MCS-12 (mean \pm SD) & $46.45 \pm 8.5$ \\
\hline PCS-12 (mean \pm SD) & $42.54 \pm 7.3$ \\
\hline ELFS (mean \pm SD) & $61.53 \pm 10.50$ \\
\hline MCS: mental component summary; PCS: physical component summary \\
\hline ELFS: lower extremity functional scale \\
\hline SD: standard deviation \\
\hline
\end{tabular}

Patients with pin-track infections were found to be more than three times as likely to sustain deep infection and chronic osteomyelitis (odd ratio $[\mathrm{OR}]=24.332, \mathrm{p}=0.017$ ) (Table 4). No significant factor was identified to influence fracture healing related complications. However, patients with Gustilo Type IIIA 
fractures $[\mathrm{OR}=5.9]$ and those treated with a monoplanar external fixator $[\mathrm{OR}=6.9]$ were found to be more at risk to develop fracture healing problems (Table 5). Fisher's exact test analysis revealed an association between improved functional outcome and biplanar LDEF, in comparison with monoplanar constructs ( $p$ $=0.039)$.

Table 4

Results of multiple logistic regression to identify risk factors of infection

\begin{tabular}{|llll|}
\hline Independent variables & Coefficient \pm SE & Odds ratio [LCI-UCI] & P value \\
\hline Age (years) & $-0.0432 \pm 0.0544$ & $0.958[0.861-1.065]$ & 0.427 \\
\hline Admission delay (hours) & $-0.105 \pm 0.0922$ & $0.900[0.752-1.079]$ & 0.255 \\
\hline Location of fracture & $-0.129 \pm 1.242$ & $0.879[0.0770-10.032]$ & 0.917 \\
\hline Gustilo grading & $1.563 \pm 1.259$ & $4.774[0.405-56.281]$ & 0.214 \\
\hline Treatment delay & $0.0463 \pm 0.0385$ & $1.047[0.971-1.130]$ & 0.230 \\
\hline External fixator & $1.728 \pm 1.344$ & $5.629[0.404-78.416]$ & 0.199 \\
\hline Pin track infection & $\mathbf{3 . 1 9 2} \pm 1.334$ & $\mathbf{2 4 . 3 3 2 [ 1 . 7 8 0 - 3 3 2 . 5 6 3 ]}$ & $\mathbf{0 . 0 1 7}$ \\
\hline Signifiant Independent variable is bold & & \\
\hline SE: standard error & & & \\
\hline LCl: $5 \%$ lower confidence interval; UCl: $95 \%$ upper confidence interval & \\
\hline
\end{tabular}

Table 5

Results of multiple logistic regression to identify risk factors of bones complications

\begin{tabular}{|llll|}
\hline Independent variables & Coefficient \pm SE & Odds ratio [LCI-UCI] & P value \\
\hline Age (years) & $-0.0198 \pm 0.0370$ & $0.980[0.912-1.054]$ & 0.592 \\
\hline Gustilo grading I-Il versus III & $\mathbf{1 . 7 7 5 \pm 1 . 0 3 7}$ & $\mathbf{5 . 9 0 2 ~ [ 0 . 7 7 3 - 4 5 . 0 7 8 ]}$ & $\mathbf{0 . 0 8 7}$ \\
\hline Treatment delay & $-0.0213 \pm 0.0342$ & $0.979[0.915-1.047]$ & 0.534 \\
\hline External fixator monoplanar versus biplanar & $\mathbf{1 . 9 4 2 \pm 1 . 0 3 4}$ & $\mathbf{6 . 9 7 1}[\mathbf{0 . 9 1 9 - 5 2 . 9 0 6}]$ & $\mathbf{0 . 0 6 0}$ \\
\hline Pin-track infection & $1.343 \pm 0.987$ & $3.832[0.554-26.501]$ & 0.173 \\
\hline Deep infection & $-0.0831 \pm 1.121$ & $0.920[0.102-8.277]$ & 0.941 \\
\hline SE: standard error; LCl: 5\% lower confidence interval; UCl: 95\% upper confidence interval & \\
\hline
\end{tabular}

\section{Discussion}


This Ivory Coast clinical trial employed LDEF as definitive stabilization approach for open tibia diaphyseal fractures, which resulted in a union rate exceeding $70 \%$, without any fixator failure and good functional outcomes.

The current study outcomes have shown LDEF to provide a safe and effective treatment modality for treating open tibial diaphyseal fractures, resulting in significant improvements as compared to our previous series without LDEF (Table 6) [7]. In addition, the union rate compares favorably with the outcomes reported by other authors [19, 26-31]. 
Table 6

Comparison of open tibia fracture management without and with locally-developed external fixators in our hospital

\begin{tabular}{|c|c|c|c|c|}
\hline & & $\begin{array}{l}\text { Without locally- developed } \\
\text { external fixators }\end{array}$ & $\begin{array}{l}\text { With locally- developed } \\
\text { external fixators }\end{array}$ & $\begin{array}{l}P \\
\text { value }\end{array}$ \\
\hline Patients (n) & & 43 & 40 & \\
\hline $\begin{array}{l}\text { Age (years) } \\
\text { mean } \pm \text { SD }\end{array}$ & & $33.3 \pm 14.1$ & $32.8 \pm 12.6$ & 0.927 \\
\hline \multirow{3}{*}{$\begin{array}{l}\text { Group of Age } \\
\text { (n) }\end{array}$} & & & & 0.733 \\
\hline & $\geq 30$ years old & 21 & 22 & \\
\hline & $<30$ years old & 22 & 18 & \\
\hline \multirow[t]{3}{*}{ Gender (n) } & & & & 0.120 \\
\hline & Male & 38 & 29 & \\
\hline & Female & 5 & 11 & \\
\hline \multirow[t]{3}{*}{ Mechanism (n) } & & & & 0.934 \\
\hline & RTA & 40 & 38 & \\
\hline & Other & 3 & 2 & \\
\hline \multirow[t]{3}{*}{ Gustilo (n) } & & & & 0.129 \\
\hline & I and II & 30 & 16 & \\
\hline & III & 13 & 24 & \\
\hline \multirow{3}{*}{$\begin{array}{l}\text { Type of } \\
\text { fracture }(n)\end{array}$} & & & & 0.044 \\
\hline & $\begin{array}{l}\text { Comminuted } \\
\text { fracture }\end{array}$ & 30 & 36 & \\
\hline & $\begin{array}{l}\text { Simple } \\
\text { fracture }\end{array}$ & 13 & 4 & \\
\hline \multirow[t]{3}{*}{ Site of fracture } & & & & 0.985 \\
\hline & Middle third & 27 & 26 & \\
\hline & $\begin{array}{l}\text { Prox/distal } \\
\text { third }\end{array}$ & 16 & 14 & \\
\hline $\begin{array}{l}\text { Treatment } \\
\text { delay }(n)\end{array}$ & & & & 0.292 \\
\hline
\end{tabular}

SD: standard deviation; RTA: road traffic accident 


\begin{tabular}{|c|c|c|c|c|}
\hline & & $\begin{array}{l}\text { Without locally- developed } \\
\text { external fixators }\end{array}$ & $\begin{array}{l}\text { With locally- developed } \\
\text { external fixators }\end{array}$ & $\begin{array}{l}P \\
\text { value }\end{array}$ \\
\hline & $>24$ hours & 21 & 14 & \\
\hline & $\leq 24$ hours & 22 & 26 & \\
\hline $\begin{array}{l}\text { Union delay } \\
\text { (months) }\end{array}$ & & $5.73 \pm 0.84$ & $8.47 \pm 1.64$ & 0.001 \\
\hline \multirow[t]{3}{*}{ Union rate $(\mathrm{n})$} & & & & 0.001 \\
\hline & $\begin{array}{l}\text { Without } \\
\text { complications }\end{array}$ & 15 & 29 & \\
\hline & $\begin{array}{l}\text { Bony } \\
\text { complications }\end{array}$ & 28 & 11 & \\
\hline \multirow[t]{3}{*}{ Infection (n) } & & & & 0.504 \\
\hline & Superficial & 11 & 13 & \\
\hline & Deep & 11 & 7 & \\
\hline \multirow{5}{*}{$\begin{array}{l}\text { Complications } \\
\text { (n) }\end{array}$} & & & & 0.004 \\
\hline & Mal-union & 17 & 3 & \\
\hline & Non-union & 0 & 4 & \\
\hline & Osteomyelitis & 8 & 4 & \\
\hline & $\begin{array}{l}\text { Septic non- } \\
\text { union }\end{array}$ & 3 & 0 & \\
\hline \multirow[t]{3}{*}{$\begin{array}{l}\text { Functional } \\
\text { outcomes (n) }\end{array}$} & & & & $\begin{array}{l}< \\
0.001\end{array}$ \\
\hline & Satisfactory & 16 & 32 & \\
\hline & Unsatisfactory & 27 & 8 & \\
\hline
\end{tabular}

This positive outcome may be accounted for by the external fixators' inherent stability, operative technique used, adherence to basic surgical principles, and efforts to achieve anatomical reduction including axial and side-to-side compression. As for the quality of fracture reduction, uniplanar devices with a rigid side-bar are usually more difficult to adjust, and the surgeon must thus take care to ensure a satisfactory reduction before the external fixator is applied. Moreover, functional results proved to be superior when a biplanar frame was used. 
A good initial reduction is essential when a fixator is applied, given that it is often difficult to achieve a secondary reduction in the case that the primary reduction proves unsuccessful. Moreover, the frame must be maintained long enough to prevent a secondary loss of fracture reduction [32]. The time to achieve union with external fixators varies in different studies $[19,28,29]$. In our study, the mean union (8.47 months) was similar to that reported by Giannoudis et al. [28]. However, shorter times have been published in the literature, as well [27,32]. The long time to union observed in our study can be explained by LDEF's rigidity. Indeed, a rigid fixation does not enable inter-fragmentary motion and, thus, tends to suppress callus formation, resulting in more direct bone healing [29], yet prolonged healing times [33].

The major drawbacks of external fixators are the inadequate primary reduction and insufficient mechanical stability leading to alignment loss, delayed union or non-union [29, 33], need for re-operation, as well as to pin-tract infections [29].

In our study, the $10 \%$ incidence of non-union observed aligned with the $8 \%$ non-union incidence noted by Beltsios et al.[29, 32]. Nonetheless, these incidence rates were lower than those published by other authors in the literature, who reported non-union rates of $13 \%, 14.7 \%, 18.7 \%$, and $28.3 \%$, respectively [26, $31,34,35]$. While this non-union rate observed in our study can be explained by the biology and biomechanics of segmental fractures, it is not to be accounted for by disadvantages of the external fixation method. Comminuted fractures, associated with significant periosteal- and soft tissue-injury, often result in non-union [27]. A segmental fracture of a long bone indirectly implies that enormous energy has been absorbed by this injury type, and that the two-level fracture pattern impairs or disrupts the intramedullary blood supply to the middle fragment. In the event of a severe soft tissue trauma, the periosteal blood supply to the middle fragment may also be compromised, thereby leading to a higher probability of delayed union or non-union [26].

In the current study, the mal-union rate amounted to $7.5 \%$, whereas in two tibia fracture cases, there was a $>1.5 \mathrm{~cm}$ shortening that did not result in significant disability. While only a few authors reported similar rates [29-32, 36], most of the others revealed higher rates, such as $26 \%, 20 \%, 25 \%, 17 \%$, and $31 \%$; respectively $[28,34,35,37,38]$. These differences could be explained by the great efforts that the authors made to achieve an anatomic reduction, in addition to the extreme stability offered by the LDEF.

PTI is a known complication following fracture treatment with external fixators whose literature-reported incidence rates range from 32 to $80 \%$, with an average $4 \%$ of cases developing chronic osteomyelitis [28, $32,34,39]$. We have herein reported a $32.5 \%$ PTI rate, along with osteomyelitis noted in two cases $(5 \%)$. Using the pin-site care protocol and discharge instructions comprising detailed guidance, patients suffering from pin-track infections received timely and successful oral antibiotic treatment [16].

The literature reveals differences in deep infection rates when external fixation is applied for definitive fracture treatment [40]. In our study, the deep infection rate amounted to $17.5 \%$. This figure perfectly aligns with the $18.1 \%$ rate observed by Alhammoud [40]. In the article Giannoudis, which reviewed 536 open tibia fractures, an average $16.2 \%$ deep infection rate was reported, which turns out to be slightly lower than our result, though roughly comparable [28]. This result could be explained by a higher rate of 
PTI, as suggested by the multiple logistic regression analysis in which only PTI remained predictive of postoperative infection $(p=0.017)$. The important delay in fracture management was not associated with an increased complication rate. Literature does not support a clear correlation between preoperative time and onset of infectious complications [41]. However, the delay in managing open fractures should not be condoned because the risk of infection that is always present is indeed multifactorial, especially after 24 hours, regardless of the degree of opening and the time taken for debridement [42]. The quality of the initial debridement is paramout, as it most likely conditions the future.

The final results were assessed according to Kitoto et al [20] criteria. In our study, the functional outcomes were satisfactory and even superior to those reported by other authors $[7,20]$. The mean SF-12 physical and mental scores of 42 and 46 , respectively, were deemed low as compared with the normal population, thereby reflecting these injuries' severity [25]. The LEFS questionnaire analysis revealed that the lower extremity's overall function was in 'a little bit of difficulty' category. The study patients were mostly young, motivated, and cooperative, which may account for the quality of LEFS scores that are somewhat equivalent to those recorded in the general population. Biplanar LDEF frames offered a better functional result, which is probably related to the more stable construct, with quicker and easier loadbearing for the patient.

We believe that in developing countries like Ivory Coast, with heavy economic constraints, a locallydeveloped external fixation should be an acceptable therapeutic modality. This frame is particularly useful in hospitals devoid of local medical facilities where patients tend to arrive late. External fixation is technically less demanding, and no specialized equipment is necessary [35, 43].

External fixation is a simple technique if used selectively and provided that the basic principles are adhered to [44]. The correct application of the external fixator on the initial lesions likely contributes to reduce the infection rates, improve the fracture consolidation, and facilitate the limb's functional recovery.

The present study's limitations are as follows: (1) small sample size; (2) no comparison with other fixation methods; (3) no randomization of study participants.

\section{Conclusion}

Overall, this study lays the foundations for further discussions and thoughts about resource allocations and cost-effectiveness of managing open tibial injuries. While we must treat our patients using the least expensive methods, the latter must also prove their effectiveness. The clinical results obtained with locally-developed external fixators as definitive treatments for open tibial diaphyseal fractures compare favorably with those recorded when using more prestigious yet expensive methods. These results reinforce the interest and usefulness in developing external fixators with locally available material.

\section{Abbreviations}

LEFS: Lower Extremity Functional Scale; 
LDEF: Locally Developed External Fixator;

MCS: Mental Component Summary;

OTDF: Open Tibial Diaphyseal Fractures;

POP: Plaster of Paris;

PCS: Physical Component Summary;

PTI: Pin-track infection;

SF-12:12-Item Short Form Survey.

\section{Declarations}

\section{Authors' contributions:}

KJEK: conception and design, data collection and analysis, and manuscript writing

JRA: data collection, patient follow-up, and manuscript revision

AAK: data collection, patient follow-up, and manuscript revision

LF: manuscript revision

CD: statistics, data analysis, and manuscript revision

MK: manuscript revision

OCo: project manager, conception and design, and manuscript revision

\section{Funding:}

UCLouvain cooperation funding

Declaration:

Ethics approval and consent to participate

\section{Availability of data and materials:}

The datasets used or analyzed during the current study are available from the corresponding author on reasonable request.

Consent for publication: 
yes

\section{Competing interests:}

The authors declare that they have no competing interest.

\section{References}

1. Elniel AR, Giannoudis PV. Open fractures of the lower extremity: Current management and clinical outcomes. EFORT Open Rev. 2018;3(5):316-325.

2. Clelland SJ, Chauhan P, Mandari FN. The epidemiology and management of tibia and fibula fractures at Kilimanjaro Christian Medical Centre (KCMC) in Northern Tanzania. Pan Afr Med J.2016;25:51. 10.11604/pamj.2016.25.51.10612

3. Krah K, Yao L, Séry B, M'bra K, Benié A, Kouassi K, et al. Données épidémiologiques des accidents de moto aux urgences chirurgicales du chu de Bouaké. Rev Int Sc Med. 2013; 15(3):161-64.

4. Bhandari M, Guyatt G, Tornetta P, Schemitsch EH, Swiontkowski M, Sanders D, Walter SD. Randomized trial of reamed and unreamed intramedullary nailing of tibial shaft fractures. $J$ Bone Joint Surg Am. 2008;90(12):2567-78.

5. Haonga BT, Liu M, Albright P, Challa ST, Ali SH, Lazar AA, Eliezer EN, Shearer DW, Morshed S. Intramedullary Nailing Versus External Fixation in the Treatment of Open Tibial Fractures in Tanzania: Results of a Randomized Clinical Trial. J Bone Joint Surg Am. 2020;102(10):896-905.

6. Wani N, Baba A, Kangoo K, Mir M. Role of early llizarov ring fixator in the definitive management of type II, IIIA and IIIB open tibial shaft fractures. Int Orthop. 2011;35(6):915-23.

7. Kouassi KJ-E, Manon J, Fonkoue L, Kodo M, Detrembleur C, Cornu O. La prise en charge des fractures ouvertes de jambe dans une structure hospitalière en Côte d'Ivoire pose-t-elle problème et pourquoi? Rev Chir Orthop Trauma. 2019;105(5):654-58.

8. Aneel Bhangu AOA, Maria Lorena Aguilera et al. Surgical site infection after gastrointestinal surgery in high-income, middle-income, and low-income countries: a prospective, international, multicentre cohort study. Lancet Infect Dis. 2018;18(5):516-25.

9. Fast O, Fast C, Fast D, Veltjens S, Salami Z, White MC. Limited sterile processing capabilities for safe surgery in low-income and middle-income countries: experience in the Republic of Congo, Madagascar and Benin. BMJ Glob Health. 2017;2(4):e000428.

10. Bach O, Hope MJ, Chaheka CV, Dzimbiri KM. Disability can be avoided after open fractures in Africaresults from Malawi. Injury. 2004;35(9):846-851.

11. Noor MA. A simple and inexpensive external fixator. Injury. 1988;19(6):377-8.

12. Kouassi KJ, Cartiaux O, Fonkoué L, Detrembleur C, Cornu O. Biomechanical study of a low-cost external fixator for diaphyseal fractures of long bones. J Orthop Surg Res. 2020;15(1):247.

13. Gustilo RB, Merkow RL, Templeman D. The management of open fractures. J Bone Joint Surg Am. 1990;72(2):299-304. 
14. Inan M, Halici M, Ayan I, Tuncel M, Karaoglu S. Treatment of type IIIA open fractures of tibial shaft with Ilizarov external fixator versus unreamed tibial nailing. Arch Orthop Trauma Surg. 2007;127(8):617-623.

15. Kaftandziev I, Pejkova S, Saveski J. Operative treatment of III grade open fractures of the tibial diaphysis. Prilozi. 2006;27(1):121-131.

16. Hao ZC, Xia Y, Xia DM, Zhang YT, Xu SG. Treatment of open tibial diaphyseal fractures by external fixation combined with limited internal fixation versus simple external fixation: a retrospective cohort study. BMC Musculoskelet Disord 2019;20(1):311. 10.1186/s12891-019-2679-9

17. Manon J, Detrembleur C, Van de Veyver S, Tribak K, Cornu O, Putineanu D. Predictors of mechanical complications after intramedullary nailing of tibial fractures. Orthop Trauma Surg Res. 2019;105(3):523-7.

18. Tribble DR, Lewandowski LR, Potter BK, Petfield JL, Stinner DJ, Ganesan A, Krauss M, Murray CK. Osteomyelitis Risk Factors Related to Combat Trauma Open Tibia Fractures: A Case-Control Analysis. J Orthop Trauma. 2018;32(9):e344-e353.

19. Tekin A, Saygılı MS, Adaş M, Çabuk H, Arslan SM, Dedeoğlu SS. Outcome of Type 3 Open Tibial Diaphyseal Fractures Managed with a Limb Reconstruction System: Analysis of a 49-Patient Cohort. Med Princ Pract. 2016;25(3):270-5.

20. Kitoko RA, Asolanyongo M, Losimba J, Georis P, Gillet P, Bruyère O. Pratique de l'ostéosynthèse des fractures de jambe en République démocratique du Congo. Rev Chir Orthop Trauma. 2016;102(3):306-9.

21. Binkley JM, Stratford PW, Lott SA, Riddle DL. The Lower Extremity Functional Scale (LEFS): scale development, measurement properties, and clinical application. North American Orthopaedic Rehabilitation Research Network. Phys Ther. 1999;79(4):371-383.

22. Theriault $B$, Turgeon AF, Pelet S. Functional impact of tibial malrotation following intramedullary nailing of tibial shaft fractures. J Bone Joint Surg Am. 2012;94(22):2033-2039.

23. Schep NW, van Lieshout EM, Patka P, Vogels LM. Long-term functional and quality of live assessment following post-traumatic distraction osteogenesis of the lower limb. Strategies Trauma Limb Reconstr. 2009;4(3):107-112.

24. Gandek B, Ware JE, Aaronson NK, Apolone G, Bjorner JB, Brazier JE, et al. Cross-validation of item selection and scoring for the SF-12 Health Survey in nine countries: results from the IQOLA Project. International Quality of Life Assessment. J Clin Epidemiol. 1998;51(11):1171-8.

25. Ferguson M, Brand C, Lowe A, Gabbe B, Dowrick A, Hart M, Richardson M. Outcomes of isolated tibial shaft fractures treated at level 1 trauma centres. Injury. 2008;39(2):187-195.

26. Milenkovic S, Mitkovic M, Mitkovic M. External fixation of segmental tibial shaft fractures. Eur J Trauma Emerg Surg. 2020;46(5):1123-7.

27. Dall'Oca C, Christodoulidis A, Bortolazzi R, Bartolozzi P, Lavini F. Treatment of 103 displaced tibial diaphyseal fractures with a radiolucent unilateral external fixator. Arch Orthop Trauma Surg. 2010;130(11):1377-82. 
28. Giannoudis PV, Papakostidis $C$, Roberts $C$. A review of the management of open fractures of the tibia and femur. J Bone Joint Surg Br. 2006,88(3):281-9.

29. Beltsios M, Mavrogenis AF, Savvidou OD, Karamanis E, Kokkalis ZT, Papagelopoulos PJ. Ball-joint versus single monolateral external fixators for definitive treatment of tibial shaft fractures. Eur $\mathrm{J}$ Orthop Surg Traumatol. 2014;24(5):821-8.

30. Milenković S, Mitković MJAfmN. External Fixation of Extra-Articular Open Tibial Fractures. Acta Fac Med Naiss. 2018;35(4):330-6.

31. Golubović I, Ristić B, Stojiljković P, Ćirić M, Golubović I, Radovanović Z, Petrović S, Djordjević N, Golubović Z, Najman S. Results of open tibial fracture treatment using external fixation. Srp Arh Celok Lek. 2016;144(5-6):293-299.

32. Beltsios M, Savvidou O, Kovanis J, Alexandropoulos P, Papagelopoulos P. External fixation as a primary and definitive treatment for tibial diaphyseal fractures. Strategies Trauma Limb Reconstr. 2009;4(2):81-87.

33. Emami A, Mjöberg B, Karlström G, Larsson S. Treatment of closed tibial shaft fractures with unilateral external fixation. Injury. 1995;26(5):299-303.

34. Kimmel RB. Results of treatment using the Hoffmann external fixator for fractures of the tibial diaphysis. J Trauma 1982;22(11):960-5.

35. Piwani M, Bhutto IA, Ahmed I. Evaluation of AO external fixator in the management of open diaphysial fracture of tibia gustilo type IIIA and IIIB. Gomal J Med Sci. 2015;13(1):66-9.

36. Bali K, Aggarwal S, Kumar V, Mootha AK, Rawall S, Tahasildar N, et al. Operative management of type II and type Illa open tibial fractures presenting from 6-24 hours after injury: an Indian experience. Curr Orthop Prat. 2011;22(3):262-6.

37. Khan MA, Khan SW, Qadir RI. Role of exteranl fixator in the Management of Type-II and III open Tibial Fracture. J Postgrad Med Inst. 2004;18(1)12-17.

38. Henley MB, Chapman JR, Agel J, Harvey EJ, Whorton AM, Swiontkowski MF. Treatment of type II, IIIA, and IIIB open fractures of the tibial shaft: a prospective comparison of unreamed interlocking intramedullary nails and half-pin external fixators. J Orthop Trauma. 1998;12(1):1-7.

39. Velazco A, Fleming LL. Open fractures of the tibia treated by the Hoffmann external fixator. Clin Orthop Relat Res. 1983(180):125-132.

40. Alhammoud A, Maaz B, Alhaneedi GA, Alnouri M. External fixation for primary and definitive management of open long bone fractures: the Syrian war experience. Int Orthop. 2019; 43(12):266170.

41. Tripuraneni K, Ganga S, Quinn R, Gehlert R. The effect of time delay to surgical debridement of open tibia shaft fractures on infection rate. Orthopedics. 2008;31(12):1-5.

42. Duyos OA, Beaton-Comulada D, Davila-Parrilla A, Perez-Lopez JC, Ortiz K, Foy-Parrilla C, LopezGonzalez F. Management of Open Tibial Shaft Fractures: Does the Timing of Surgery Affect Outcomes? J Am Acad Orthop Surg. 2017;25(3):230-238. 
43. Museru LM, McHaro $\mathrm{CN}$ : The dilemma of fracture treatment in developing countries. Int Orthop. 2002;26(6):324-327.

44. Padhi NR, Padhi P. Use of external fixators for open tibial injuries in the rural third world: panacea of the poor? Injury. 2007;38(2):150-9.

\section{Figures}

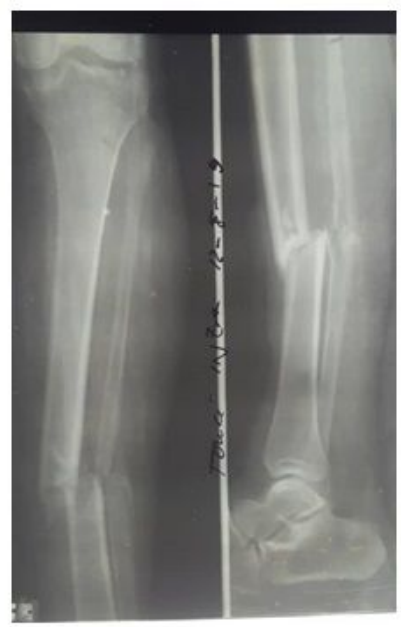

a

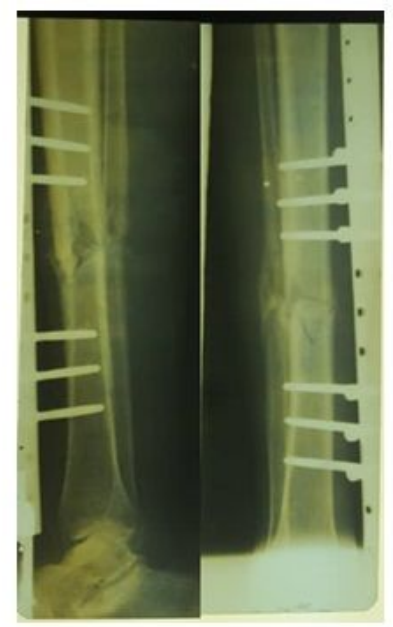

b

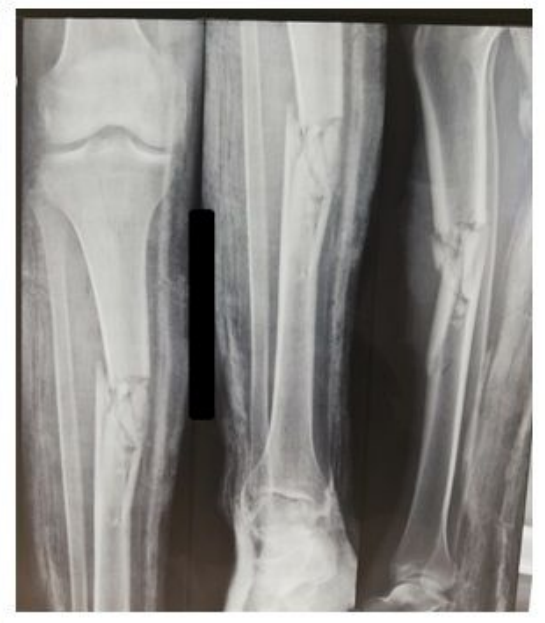

C

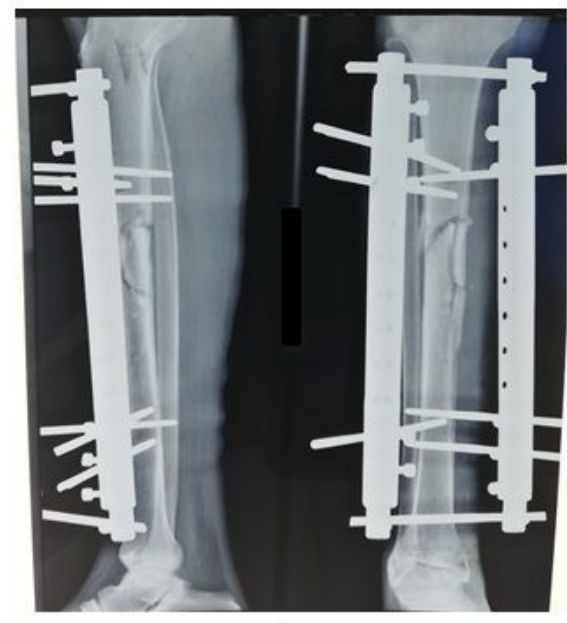

d

\section{Figure 1}

Diaphyseal tibia fractures treated with LDEF. a Transversal tibia fracture. $b$ Treatment using monoplanar external fixator. c Communited tibia fracture. $d$ Treatment using biplanar external fixator 


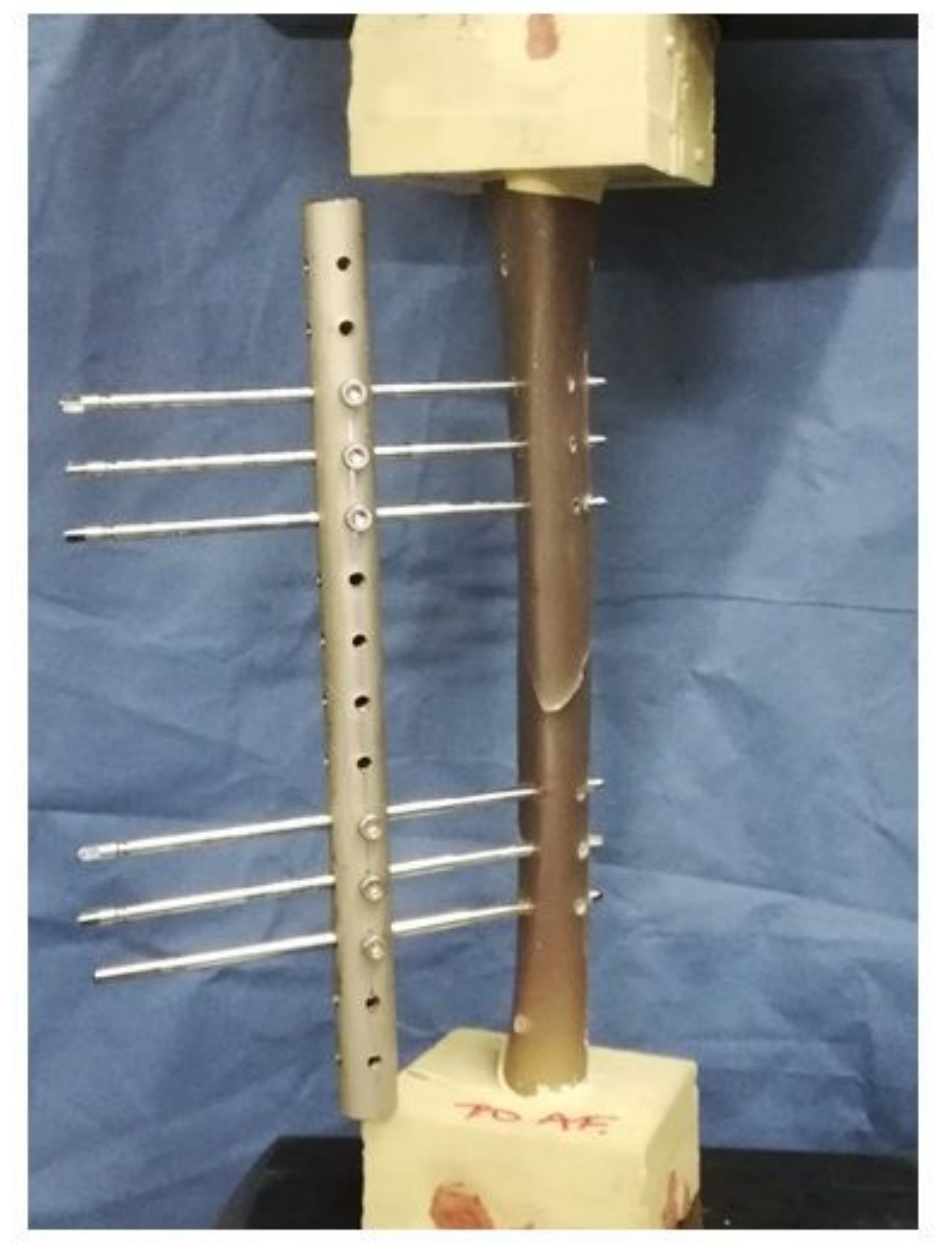

a

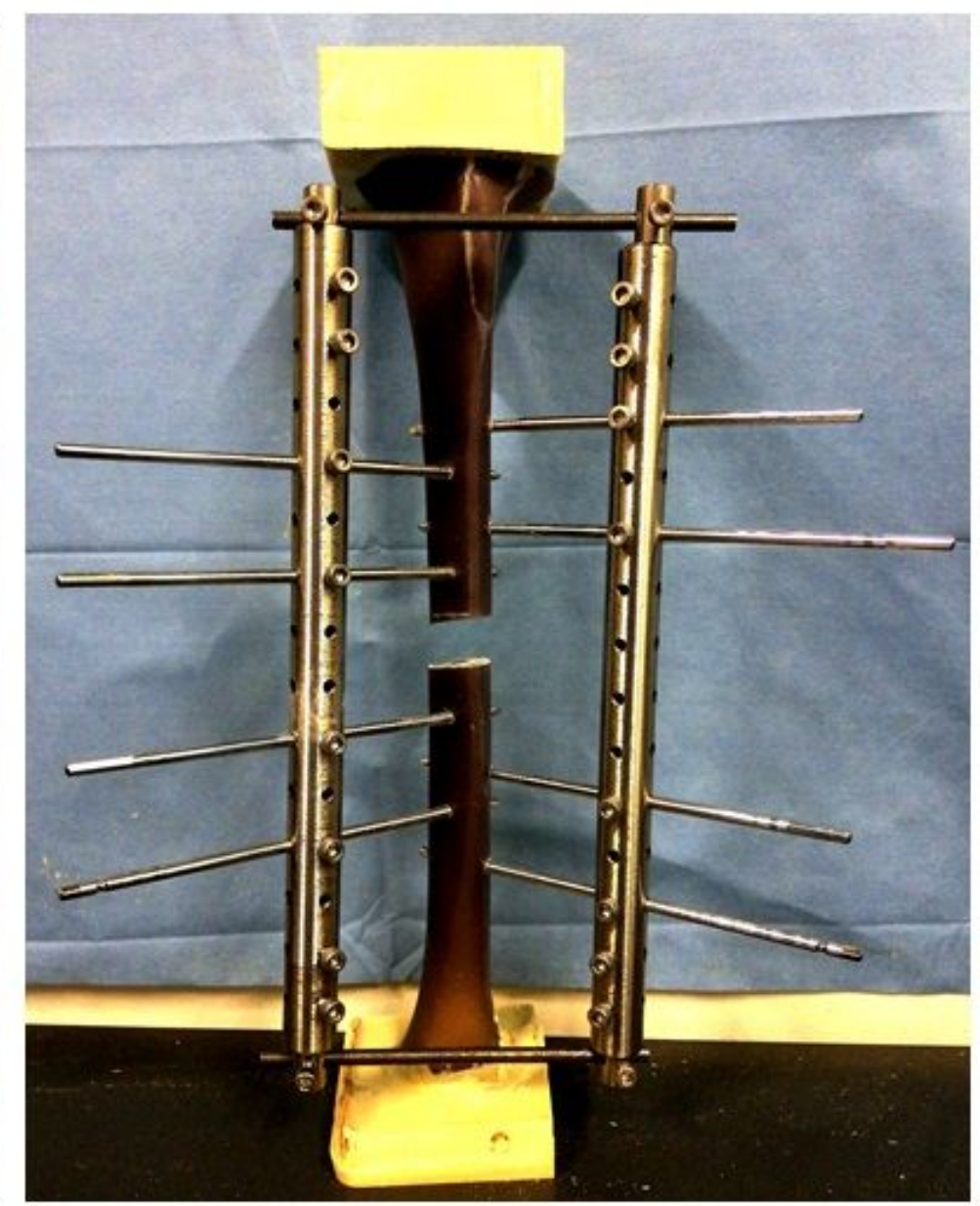

b

\section{Figure 2}

Illustrations with a saw bone of monoplanar (a) and biplanar fixations (b) of oblique single (a) and comminuted/bone defect fractures (b)

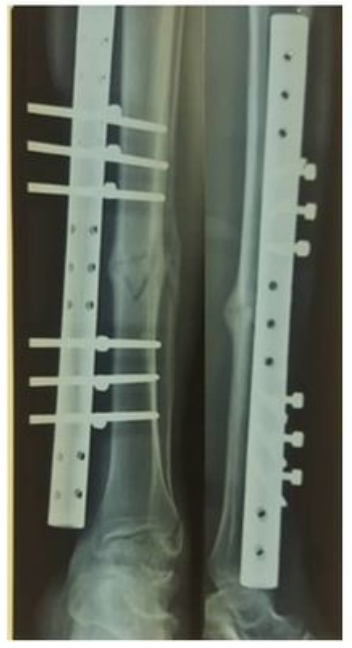

a

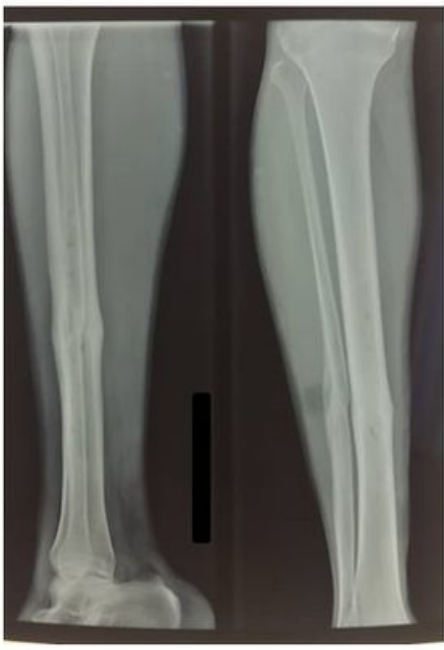

b

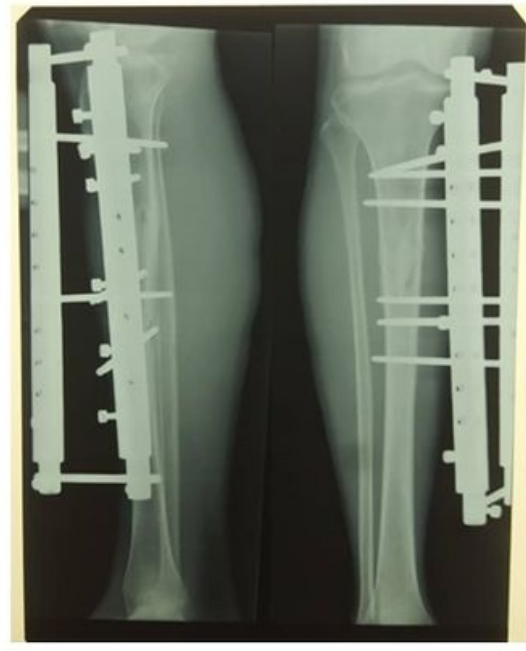

C

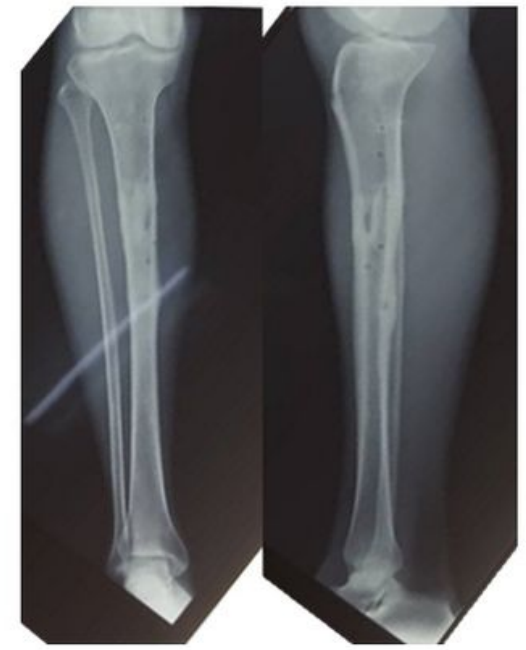

d

Figure 3 
Radiographs at 6 months after the initial operation (a, c ) and at final follow-up after LDEF removal (b, d)

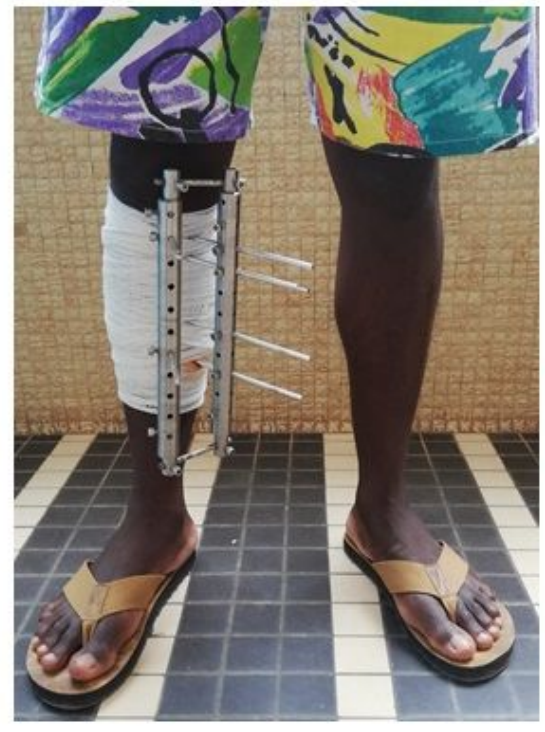

a

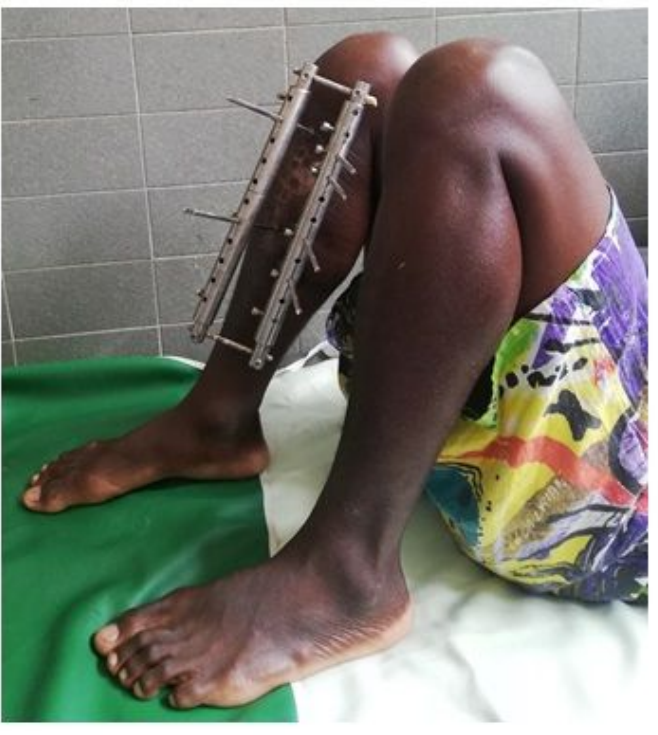

b
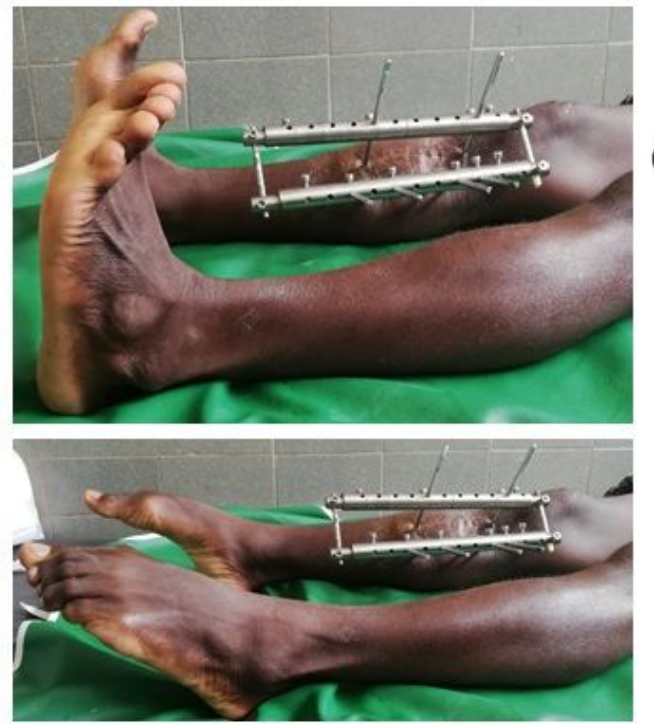

C

Figure 4

Clinical images with LDEF biplanar showing functional outcome. a Clinical appearance. b Knee flexion of the patient with LDEF. c Ankle plantar flexion. d Ankle dorsiflexion 